\title{
Study and Thought on Sino-Foreign Cooperative Education in Higher Vocational Colleges in Jiangsu Province
}

\author{
Li Zhang ${ }^{1}$ \\ ${ }^{1}$ School of International Education, Nanjing Institute of Industry Technology, Nanjing, China \\ Correspondence: Li Zhang, School of International Education, Nanjing Institute of Industry Technology, Nanjing \\ 210046, Jiangsu, China. E-mail: zhangl1@niit.edu.cn
}

Received: July 23, 2012 Accepted: August 6, 2012 Online Published: December 31, 2012

doi:10.5539/ass.v9n1p112

URL: http://dx.doi.org/10.5539/ass.v9n1p112

\begin{abstract}
With continuously deepened internationalization of education, "internationalization of local talents and localization of international talents has become a tendency". Sino-foreign cooperative education in higher vocational colleges is vigorously developed and has achieved unprecedented expansion and development in terms of both scale and level. Ever since higher vocational colleges in Jiangsu Province conducted Sino-foreign cooperative education, they have achieved a series of important educational achievements and have exerted great influences in all walks of the society. Indeed, the primary purpose of Sino-foreign cooperative education in higher vocational colleges is to bring in excellent education resources, and promoting educational and teaching reform is a perfect resource carrier and learning carrier, but among a multitude of Sino-foreign cooperative education projects, the phenomenon of dragons and fished jumbled together also exists. And the various problems revealed in the process of education have seriously damaged the cultivation quality and reputation of Sino-foreign cooperative education. This paper is going to discuss and analyze in details problems implied in Sino-foreign cooperative education in higher vocational colleges from twelve aspects. These difficulties constrain the healthy development of Sino-foreign cooperative education in higher vocational colleges and have to be practically emphasized and resolved.
\end{abstract}

Keywords: Sino-foreign cooperative education, problem, countermeasure

In order to further standardize management of Sino-foreign cooperative education management, improve quality of Sino-foreign cooperative education, carry out the Sino-foreign cooperative education working strategy of "enlarging openness, standardizing cooperative education, administering in pursuant to the law and promoting development" established in "Regulations of the People's Republic of China on Sino-Foreign Cooperative Education", the key assessment content is whether a feasible teaching quality process guarantee system has been established according to the major content in assessment of the Ministry of Education on Sino-foreign cooperative education institutions about quality process guarantee system. The assessment contains, teacher recruitment system, school census system, teaching management regulation, teaching quality assessment system and implementation of the system; whether teaching quality process guarantee system has been set up and mechanism of functioning of the institution, supervision mechanism and implementation condition and operation effect; whether a feedback mechanism and incentive mechanism to guarantee constant improvement of education quality and condition of implementation, etc. Therefore, it is imperative to enhance teaching quality of Sino-foreign cooperative education, while the current Sino-foreign cooperative education in higher vocational colleges has a lot of problems. Sino-foreign cooperative education in higher vocational colleges is not supported, the capacity of administration department is obvious inadequate, introduction of excellent education resources has a great gap, internationalized teacher team construction is not effective, the entrance performance of students in Sino-foreign cooperative education is too low, the country has not strictly carried out its regulations on bringing in foreign teachers, requirement of the proportion of foreign curriculum has not been strictly implemented, and the form of Sino-foreign cooperative education that cries up wine and sells vinegar has not been supervised. Thus, the society has not had high recognition to Sino-foreign cooperative education management in higher vocational colleges and establishment of quality guarantee mechanism is still open for further improvement. Discussion on problems existing in Sino-foreign cooperative education in higher vocational colleges and proposing specific resolution countermeasures with pertinence can ensure sustainable development of Sino-foreign cooperative education in higher vocational colleges in China. 


\section{Incomplete Teaching Management and Assessment System}

In teaching in higher vocational colleges, as a quality management instrument, assessment system has good orientation, stimulation and supervision functions. Combined together, these functions become the teaching quality guarantee system in higher vocational colleges. Meanwhile, these functions are the motive power of teaching quality management system and continue to affect quality of teaching and learning in higher vocational colleges. According to "Questionnaire Survey Report on Internationalization of Education in Higher Vocational Colleges in Jiangsu Province", among the 54 higher vocational colleges investigated, there are 44 colleges that have set up organizational institutions that particularly administer international affairs. Although there are some differences in terms of their calling, there are mainly two forms. One kind of institutions is the office that administers international affairs (international affairs office, international cooperation office and international exchange office, etc.), and the other kind is set up in the form of branch college (international college, international education and communication college and international cooperative college, etc.). There are 7 colleges in the sample which set up independent colleges, accounting for $12.96 \%$ of the total in the sample. Thus, it can be found that, currently, Sino-foreign cooperative education projects in a large majority of higher vocational colleges have, so far, not set up a teaching management system centered with teaching evaluation, policies of Sino-foreign cooperative education in higher vocational colleges are not adequate and the capacity of intramural education management department is obviously inadequate, which makes it impossible to satisfy teaching evaluation methods with different requirements. Thus, we are supposed to establish effective, practical and feasible assessment system.

In accordance with the requirement, higher vocational colleges all list articles about supervision institution and assessment mechanism in cooperative education in their agreement on formal school running in the process of cooperative education. However, in the process of cooperative education, as a consequence of regional differences and time differences, the supervision institution fails to play its full supervision function and it is also difficult for the assessment mechanism to have a unified standard. Some cooperative colleges have set up offices at home, and they are able to well perform their supervision on the curriculum and teaching. At the end of a school semester, they promulgate corresponding assessment method and give the feedback of the assessment to the counterpart. Nevertheless, some colleges have a low foundation and have not had any experience in cooperative education. Therefore, they regard cooperative education as a pure commercial behavior. With this concept in the mind, they pay attention to profitable running of the school, but ignore supervision and assessment, which becomes a sort of short-term behavior that lacks sustainability.

\section{Bad Quality of Source of Students and Weak Foundation of Students}

According to "Questionnaire Survey Report on Internationalization of Education in Higher Vocational Colleges in Jiangsu Province", it is indicated that, among the 54 colleges investigated, there are 48 colleges that mention they are currently conducting Sino-foreign cooperative education projects, while there are 22 colleges that mention they have suspended Sino-foreign cooperative education projects, accounting for a proportion of $40.7 \%$. The major reasons for suspending these projects are analyzed as below: inadequate source of students (18 colleges), bad quality of source of students ( 6 colleges), bad benefit ( 5 colleges), active suspending by foreign partners ( 3 colleges), bad teaching effect (4 colleges) and one college explains that the Ministry of Education has constrained four projects, so it suspends some Sino-foreign cooperative education projects. Thus, it can be seen that, the issue of source of students is a primary one in Sino-foreign cooperative education. At present, a large majority of students in Sino-foreign cooperative education projects are the second batch of junior college students. Thus, the entrance performance of students is relatively inferior, foundation of students in weak and a lot of teachers feel it a headache to give lectures to students in the Sino-foreign cooperative education projects.

Students in Sino-foreign cooperative education are mostly the second batch of junior college students. Since the source of students of the second batch is relatively inadequate and students have misunderstanding in existence of higher vocational colleges, there are quite a few students who register for the entrance exam of higher vocational colleges as a first choice and the rate of registration is less than $50 \%$. Sino-foreign cooperative education projects have relatively high requirement on students' ability to use English. Some individual higher vocational colleges even do not scruple to lessen their standard of recruitment in order to obtain more registered students and even have no particular requirement on performance of the subject of English. After they enter the colleges, students have to burden the double pressure of language learning and professional learning and have to accept and adapt to two different kinds of teaching systems, which is quite difficult for the second batch of junior college students who have a weak foundation of English. Thus, the result is imaginable. The students have to finally give up the foreign diploma as a result of the language barrier. 
A large majority of students in Sino-foreign cooperative education projects come from families that have a good economic condition. Since they have been cared by their parents for a long time, their independence and self-care capacity is vulnerable, their ability to bear frustration is weak, their consciousness of self-center is strong, as a result of which the discipline of the class is bad, foreign teachers and students find fault with each other and students often fail a class, and the phenomenon of failing a class is especially serious in the exam of a foreign teacher's class.

Since students have a weak foundation in Sino-foreign cooperative education, great difficulty has been brought to classroom teaching and daily management of the class. It is shown in the survey that, attendance rate of students in Sino-foreign cooperative education projects is much lower than that of regular professional students. The phenomenon of absence from the class is extremely serious and the phenomenon of being late is even more serious. Even though a large part of students can attend the class in time, their discipline in the class is quite worrisome. It can be found everywhere that students play electronic games with a cell phone and read electronic books, and the phenomenon of sleeping and un-concentrated energy is even more worrisome. Therefore, a large majority of teachers who assume the task of teaching in Sino-foreign cooperative education projects feel it a headache to teach these students. It is slightly better for teachers who teach the basic courses for freshmen. Especially when the teachers teach the subsequent courses, it is quite difficult for them to teach these courses since the basic courses of the students are not adequately ideal. Therefore, a lot of teachers are reluctant to teach courses in Sino-foreign cooperative education projects. And usually young teachers are assigned to participate in the teaching. Since they have no opportunity to be taught and guided by experienced teachers, the effect of their learning is even much worse.

Since classroom teaching can not be guaranteed, great difficulties have been brought to management of teaching and management of students. As these students have not formed a good learning habit at the stage of middle school, they have no explicit learning direction. The class adviser and instructor have to often have a heart-to-heart talk with students in terms of their discipline in the class to supervise students in abiding by all rules and regulations of the school, as there are students who violate the discipline of the school each day. Thus, student management personnel, including the teachers who assume the task of teaching, need to spend plenty of time at their spare time to educate students in terms of their quality. To help students establish a correct learning direction, form a good learning habit and correct their bad learning behaviors has become a compulsory course and a necessary task of each staff who participates in Sino-foreign cooperative education projects.

Although the colleges have allocated assistants for foreign teachers, the foreign teachers have the feeling that their teaching target is ambiguous as students' English and professional basis as well as their will of going abroad is different. Therefore, according to the target of pursuing further study and the English level of students, stratified teaching among students in Sino-foreign cooperative education is the best approach to resolve this problem. Of course, there are a lot of factors that affect sources of students in Sino-foreign cooperative education projects and how to enhance appeal of cooperative education is the path of resolving the problem.

\section{No Much Effective Construction of Internationalized Teacher Team}

According to "Questionnaire Survey Report on Internationalization of Education in Higher Vocational Colleges in Jiangsu Province", from the sample, it can be found that there are 48 colleges that indicate they have recruited foreigners to participate in teaching. The average number of foreigners engaged in teaching in higher vocational colleges in Jiangsu Province is 4.81. There are 15 colleges that indicate they have recruited foreigners to participate in administration. The average number of foreigners engaged in administration is 0.57 . There are $29.6 \%$ of colleges that have ever recruited visiting scholars and there are $92.6 \%$ of colleges that have recruited foreign experts. There are $84.91 \%$ of foreigners who are full time teachers, $19.32 \%$ of foreigners who are part time teachers and $14.82 \%$ who are administrative personnel. The situation is different in different areas. Generally speaking, the average number of foreign teachers in Changzhou and Nanjing is high. Considering the situation of recruitment of administrative personnel, among the 54 colleges in the sample, 15 colleges mention that they have at one foreign administrative personnel, among which 10 colleges indicate that the source of these administrative personnel is that according to the agreement of cooperative education, it is the foreign party that sends personnel to participate in the administrative work of the cooperative project and 5 colleges express that the administrative personnel are recruited. According to the statistics, $90.7 \%$ of colleges investigated have ever sent the domestic teachers and administrative personnel to learn and exchange with their foreign partners. $64.8 \%$ of colleges have ever sent their teachers to participate in foreign language training and $85.2 \%$ of colleges have sent their teachers to participate in foreign professional training. The major channels for domestic teachers to go abroad for foreign training contain $t$ he following: arrangement by provincial, municipal administrative organizations and institutions and above, contacting foreign institutions to train the domestic teachers by the 
colleges, the national and provincial funds for public assignment of studying abroad and applying to study abroad by students themselves.

On one hand, in the current Sino-foreign cooperative education projects, there is a great demand on foreign teachers. Some colleges are too hasty in their bringing in foreign teachers and their procedure is too simplified, so the foreign teachers they have brought in are quite uneven. On the other hand, flow of foreign teachers is too frequent, which is not helpful for them to correctly master the condition of the colleges and the students, and this is likely to lead to the problems of unsystematic teaching and lack of continuity. The international education department in some colleges has carried out methods for administration of foreign teachers, which further improves and enhances the recruitment system of foreign teachers and strengthens the supervision work of foreign teachers.

A large majority of colleges seldom pay attention to particularity of Sino-foreign cooperative education, have no obvious preferential policy for the teaching job in Sino-foreign cooperative education, or have not promulgated relevant supporting policies. Furthermore, the quality of sources of students in Sino-foreign cooperative education can not be guaranteed. This leads to more energy on development of the normal teaching than a common classroom teaching. As a result, it is difficult to attract excellent teachers to participate in the team of teachers in Sino-foreign cooperative education. Although the colleges have a lot of teachers going abroad each year for study in the past few years, they still stay in their former positions and participate in the former work after they return from abroad and they fail to apply any international experience they have learnt that deserves our reference into Sino-foreign cooperative education.

Thus, even though a lot of colleges conduct bilingual teaching according to the requirement, there are not a great many excellent teachers who have fluent expression of foreign language, solid professional foundation and who are willing and wish to devote themselves to Sino-foreign cooperative education. Therefore, in actual teaching, either the colleges replace bilingual teachers with Chinese teachers or they temporarily recruit relevant teachers from other colleges. This not only limits improvement of quality of the teaching, but also will bring about a hidden trouble to the teaching management job.

Professional international education teacher team is lacking. In terms of allocation of teachers, some colleges select teachers with intermediate and senior professional titles to shoulder the teaching task of professional courses and to attempt to implement bilingual teaching who have solid professional knowledge, young and energetic, and who have good English basis. These teachers should not only be able to provide abundant professional knowledge and skills for students, but should also have a good knowledge in international rules of the professional field. They should possess two capacities. One is the cooperative capacity, such as, cooperation in teaching, cooperation of teaching and research, cooperation in compilation of teaching material and cooperation in teaching method, etc. The other one is the learning capacity, which means that students should learn advanced foreign education ideas and teaching and administration method with an open mind in their work and life together with foreign teachers, experts and scholars so as to constantly improve themselves. In the process of cooperative education, Chinese and foreign teachers should communicate with each other frequently, learn from each other, make the best of the both worlds, discuss together the teaching mode and cooperate in developing new teaching materials. Backbone teachers should be selected and sent to relevant cooperative colleges for exchange and study. Each day, at least ten bilingual teachers should be sent to go abroad for further study. Meanwhile, the colleges should cautiously carry out and implement the document spirit of "Long and Medium Education Reform and Development Plan Outline in Jiangsu Province". According to the requirement of "Notice of the Provincial Department of Education about Selecting Excellent Young and Middle-aged Teachers and Principals to Go Abroad for Study", about five excellent young and middle-aged teachers go abroad for further study each year. Then, these teachers may personally appreciate the educational environment, teaching idea, method and means of foreign institutions of higher learning.

The bilingual teachers who shoulder the task of teaching in Sino-foreign cooperative teaching should not only possess the professional knowledge and teaching capacity of common professional teachers, but should also have solid foreign language skills and strong oral application capacity. At present, this kind of talents is still in deficiency in higher vocational colleges, and a lot of colleges choose to recruit talents with higher educational background who have good oral English competence. Nevertheless, since these young teachers have just walked out from the campus, they have no teaching experience and it is difficult for them to apply the professional knowledge they have learnt skillfully into bilingual teaching. In most cases, they choose to apply the university undergraduate teaching mode they have learnt into the bilingual teaching in higher vocational colleges, so it is unlikely to reflect special features of education in higher vocational colleges. Indeed, some teachers with senior professional titles have abundant teaching experiences, but their language skill is not strong, which constrains 
their playing in bilingual teaching. The low level of teachers and inadequate teaching effect also affect students' enthusiasm in learning, as a result of which educatees pay a high tuition fee but fail to share high-quality education resources.

\section{Teaching Mode and Assessment Means Unable to Be Geared to International Standards}

For the time being, a large part of Sino-foreign cooperative education projects still adopt the domestic traditional teaching mode in the entire teaching process. They almost use domestic relevant non-cooperative professional content whether in terms of teaching content and talent cultivation project and in terms of teaching mode and evaluation means instead of following the teaching reality of Sino-foreign cooperative professions. This kind of teaching mode, on one hand, makes students unlikely to feel the atmosphere of international education, and, on the other hand, makes students unable to adapt to teaching of teachers from the partners.

It is shown in the survey that, formulation of talent cultivation project in a large majority of cooperative projects is made by adding part of foreign language courses on the basis of existing domestic talent cultivation projects and fails to go deep to investigate the talent cultivation projects in the cooperative institutions, let alone modifying and improving foreign talent cultivation project by combining the actual situation of domestic projects. The entire teaching process almost follows the traditional domestic teaching method and the assessment mode only concentrates on the result, but ignores assessment of the process. As a consequence, students are unlikely to be affected by advanced foreign teaching mode and teaching content. However, due to particularity of Sino-foreign cooperative professions, such a mode actually is neither helpful for growth of students nor for successful development of Sino-foreign cooperative projects.

Then, requirement for proportion of the eight foreign courses has not been strictly implemented and some Sino-foreign cooperative education projects even have no foreign teachers. The former talent cultivation project in Sino-foreign cooperative education is not suitable for Sino-foreign cooperative education projects and reasonable curriculum setting is the key to cooperative education. Let's take cooperative education projects in Nanjing Institute of Industry Technology as an example. Sino-foreign cooperative projects in the School of International Education are all professions for cooperation with the cooperative institutions. The initial talent cultivation project is inappropriate whether considering the actual learning level and capacity of students or considering the talent cultivation target required by the cooperative projects. Curriculum setting is the key to Sino-foreign cooperative education projects, which requires to combine the cultivation system and standard of international cooperative institutions with local educational policies and directions in China.

\section{Low Social Recognition to Sino-foreign Cooperative Education in Higher Vocational Colleges}

Among the 54 questionnaires, 53 questionnaires are effective in their answers to the question. Among the 47 colleges with effective questionnaire who have initiated Sino-foreign cooperative education projects, 38.9\% consider the effect good, $42.6 \%$ consider it general and 5.6\% consider it bad. It can be predicted from the survey result, currently, higher vocational colleges in Jiangsu Province which have opened Sino-foreign cooperative education projects generally have no high evaluation on the projects they have opened. According to "Questionnaire Survey Report on Internationalization of Education in Higher Vocational Colleges in Jiangsu Province", it can be concluded from the effective questionnaires that, quality of source of students, difficulty in recruitment of students and language barrier are listed on the top, which proves that the three elements are the largest obstructs that affect the effect of Sino-foreign cooperative education.

This is only a survey result concluded from our institute. From the perspective of students, they have quite a low recognition to international cooperative education. Quite a large majority of students believe that international cooperative education is nothing more than increasing the tuition fee in a disguised form, as a result of which part of students who are from families with good economic conditions enter the university classroom by means of spending money for the exam score. It is also discovered through survey on students that, a large majority of students study Sino-foreign cooperative education professions not because all of them plan to go abroad for further study. Instead, that's because it is a choice they have to make as they fail to pass the regular institutions of higher learning.

Since the colleges themselves have deviation in their recognition to Sino-foreign cooperative education, and especially they can't obtain recognition by the college students, Sino-foreign cooperative education has a low recognition by the society, and the parents of the students are also unwilling to send their children to study in Sino-foreign cooperative education professions. Almost all of those who choose Sino-foreign cooperative education professions enter the classroom of Sino-foreign cooperative professions just as they fail the college entrance examination and fail to study professions in regular institutions of higher learning. Thus, there are even part of students who choose Sino-foreign cooperative professions for further study abroad regret that they have 
made such a choice.

On the contrary, we also discover that, a lot of preparation class exams for international study are also quite hot in the middle schools, especially in middle schools in Nanjing. The number of applicants for primary and middle foreign language schools is quite large and the admission ratio sometimes even attains 10:1 and even higher. We have visited a great many study-abroad intermediary agencies and find that business of these agencies is quite hot. Then, why the Sino-foreign cooperative education is so unfrequented? To this end, we have a conversation with part of the parents. According to the parents, quality of students in Sino-foreign cooperative education in higher vocational colleges at present and the study environment is not quite ideal, so they are worried that their children may be interfered by bad habits. Therefore, they would rather spend a lot to resort to intermediary agencies to help their children go abroad for further study. The primary reason is that they do not approve the current international cooperative education.

\section{Inadequate Support of the Policies}

In face of all the kinds of difficulties encountered in Sino-foreign cooperative education and in order to help Sino-foreign cooperative education get out of these difficulties, it is urgent that related units and competent departments promulgate relevant supporting and assisting policies for Sino-foreign cooperative education. Considering the great tendency of development of higher vocational education in the future, Sino-foreign cooperative education is the best way out and solution. Related units should provide corresponding preferential policies to make Sino-foreign cooperative education developed in a healthy and rapid way. For the time being, a large majority of colleges are far from enough in this regard.

Since tuition fee of Sino-foreign cooperative education projects is much higher than that of regular institutions of higher learning, quality of the source of students can't be guaranteed and the social recognition is low, the ultimate result of which is that teachers who are engaged in Sino-foreign cooperative education exert more efforts than teachers in regular institutions of higher learning. In order to ensure the quality of teaching and successful development of the entire teaching, it is necessary for teachers to try all means to attract students in the class and attract the students into their lectures. After the class, it is also necessary for the teachers to have a frequent exchange with students, spend plenty of time on correcting students' bad learning habits and rectifying their learning attitude, and guide students in forming correct outlook on life. As excellent students are in deficiency, as a result, a lot of projects about students are hard to launch and teachers have to make efforts twice or three times more than students in regular institutions of higher learning in order to achieve the same performance. However, currently, there are rarely colleges that have promulgated relevant supporting policies to help Sino-foreign cooperative projects get out of the dilemma and that have had explicit preferential policies in terms of the amount of teaching, scientific management and competition of students. It is usually based on the traditional principle of fairness that students and teachers in Sino-foreign cooperative education are asked to compete with students and teachers in regular institutions of higher learning. It is hardly realized that such fairness, as a matter of fact, is unfair. The ultimate result is that students in Sino-foreign cooperative education are unlikely to have the same opportunity of practicing as other students, which frustrates their enthusiasm, makes it difficult for the teachers to teach and further adds to burden of teachers engaged in Sino-foreign cooperative projects.

There are a large number of foreign teachers engaged in Sino-foreign cooperative projects who have no idea about source of students in the process of teaching, which leads to a lot of problems in the process of teaching. For instance, they may propose requirements on students in accordance with their local situation. Thus, disharmony exists between students and these foreign teachers, which also requires Chinese teachers to spend a lot of energy to coordinate.

\section{Irrational Cooperative Professions}

According to "Questionnaire Survey Report on Internationalization of Education in Higher Vocational Colleges in Jiangsu Province", it is found that, among the 54 higher vocational colleges in Jiangsu Province, the professions opened in Sino-foreign cooperative education include management (19), finance (17), international trade (13), construction (10), computer (9), design (7), marketing, (6), mechatronics (5), software engineering (4), mechanical engineering (4), electronic technology (4), financial (3), language (3), auto technology (3), agricultural science (3), CNC technology (2), environment monitoring and governance (2), preschool education / social work (2), golf (2), model design and manufacturing (1), chemical (1), food processing technology (1), engineering management (1), medical (1), biology(1) and Chinese language and literature (1). Professions involve multiple fields and are mainly business. The specific distribution is shown as below: 
Table 1.

\begin{tabular}{lllll}
\hline Management & Finance & $\begin{array}{l}\text { International } \\
\text { trade }\end{array}$ & Construction & Computer \\
\hline 19 & 17 & 13 & 10 & 9 \\
Design & Marketing & Mechatronics & $\begin{array}{l}\text { Software } \\
\text { engineering }\end{array}$ & Mechanical engineering \\
7 & 6 & 5 & 4 & 4 \\
$\begin{array}{l}\text { Electronic } \\
\text { technology }\end{array}$ & Financial & Auto & $\begin{array}{l}\text { Agricultural } \\
\text { science }\end{array}$ & CNC technology \\
4 & 3 & 3 & 3 & 2 \\
Environment & Social science & Golf & Model & Chemical \\
2 & 2 & 2 & 1 & 1 \\
Food processing & Engineering & Medical & Biology & $\begin{array}{l}\text { Chinese language and } \\
\text { management }\end{array}$ \\
1 & 1 & 1 & 1 & 1 \\
\hline
\end{tabular}

From the above table, it can be seen that, economics and management as the major professions in Sino-foreign cooperative projects are the main professions in the Sino-foreign cooperative professions. However, talents majoring in agricultural science and engineering are in urgent need currently and also high-end technology talents, such as, CNC technology, etc., while Sino-foreign cooperative education rarely involves these professions. The reason why professions in Sino-foreign cooperative education are economics and management is that investment in these two large professions is small. Compared with medical profession, engineering and high and new technology which often makes an investment of several million equipment, economics and management subjects only need to bring in teaching material and foreign teachers to satisfy a daily teaching task. It is a tendency for foreign cooperative institutions to show preference for arts with a great profit as the key of cooperative education. By contrast, domestic higher vocational colleges, on one hand, pursue benefit, and, on the other hand, are unable to develop other professions due to economic and academic limitations even though they intend to. It should be noted that, at present, such hot professions as economics and management have been on the verge of saturation, so they should not be regarded as the emphasis of development in the future.

Our Sino-foreign cooperative projects seldom touch upon the current international high-end technology and newly emerging industries, such as the leading and frontier professions and subjects of internet technology, new energy technology, virtual reality technique, intelligence appliance and mobile technology, which few colleges have involved. However, these advanced technology and fields are exactly the industries required by development of the country.

\section{Academic Exchange and Scientific and Research Cooperation Open for Being Strengthened}

According to statistics, $42.6 \%$ of higher vocational colleges in Jiangsu Province have ever had teachers who are invited to participate in international academic conferences held by foreign institutions and the pace of participation in foreign academic exchange has seen its obvious effect. From the statistical table, it can be seen that $18.5 \%$ of higher vocational colleges in Jiangsu Province have had experience in cooperation with foreign scientific institutions, $33.3 \%$ of higher vocational colleges have ever participated in inter-governmental cooperation, $35.2 \%$ of higher vocational colleges have ever participated in teacher academic and scientific cooperation in foreign institutions of higher learning and $16.7 \%$ of higher vocational colleges have ever had in-depth cooperation with foreign enterprises. It is concluded then that, there are $50 \%$ of higher vocational colleges having experience in cooperation with foreign institutions of higher learning who consider the effect good and 50\% who consider the effect common in their evaluation on the cooperation.

It can be seen from the above investigation result that, although academic cooperation and exchange between Jiangsu Province and foreign institutions have achieved obvious effect, their cooperation and exchange is still open for strengthening and the proportion of participating in international academic conferences is small. Especially, scientific cooperation with foreign institutions is currently quite low and cooperation and exchange with foreign enterprises is quite limited. Even though some colleges have had experience in scientific cooperation with foreign institutions, the proportion of colleges that consider the cooperative effect unsatisfactory even attains 50\%. 


\section{The Problem of Teaching Material for Bilingual Teaching and Teaching by Foreign Teachers}

Another great difficulty encountered in Sino-foreign cooperative education in higher vocational colleges is the issue of bilingual teaching. This is mainly reflected in three aspects. Firstly, students in higher vocational colleges generally have a bad English foundation, and especially the practical application competence of listening, speaking and writing is not strong, so it is difficult for them to adapt to English teaching. Secondly, the proportion of Chinese and English courses is imbalanced. Since English level of a lot of students is generally weak, quite a lot of courses can't be taught with original English version of the teaching material and teachers are unable to teach in English, so the proportion of Chinese and English courses is imbalanced. Thirdly, English teaching method is single, which is mainly caused by different teaching modes of Chinese and foreign teachers. Chinese teachers mainly teach in the mode of teaching, which is quite unfavorable for bilingual teaching that emphasizes interaction of teachers and students.

Currently, the problem of incompleteness of part of bilingual courses and teaching material of curriculum taught by foreign teachers generally exists in Sino-foreign cooperative projects. Quite a large majority of foreign teachers have not brought with them appropriate teaching materials from the cooperative institutions, so most of them use the teaching method of teaching materials. Introduction of original English version of teaching material is a basic precondition for whether bilingual teaching can be successful. Thus, on one hand, it is necessary to further play functions of original version of teaching material in cultivation of students' competence, insist on the principle of going from the easy to the difficult and step by step. On the other hand, we need to refer to advanced ideas in the original version of teaching material to promote sinicization of English teaching material and enhance teaching material at home.

So far, there has not had bilingual state-compiled textbook for higher vocational colleges. Among the colleges that develop Sino-foreign cooperative education, some bring in original version of foreign teaching material in the process of bilingual teaching and some still use bilingual teaching material designed for undergraduates at home. The overall level of students in higher vocational colleges is low. Although they have received special English training for one year, it is sometimes difficult for them to totally accept and absorb the knowledge they have learnt in the classroom to really and completely carry out full English teaching. The English version of teaching material they are taught usually only has several exercises or several experimental procedures, and has not formed a complete system of textbook. It is true that at the end of the teaching material, reference books are offered and foreign students may go to the library to look up for necessary information after class, but as for Chinese students, the library is unlikely to offer so many foreign reference books, which will necessarily lead to difficulty of students involved in Sino-foreign cooperative education in preview before class and review after class and make them unable to well enhance their existing knowledge system. Domestic undergraduate textbook is designed and compiled for undergraduate teaching, so it is inappropriate for students in higher vocational colleges that concentrate on cultivation of practical operation competence. Serious deficiency of bilingual teaching material makes bilingual teaching in higher vocational colleges become water without a source and tree without roots.

\section{The Problem of Positioning in School Running}

Under the advanced idea of vigorously broadening the talent cultivation approach, higher vocational colleges have not had an accurate school running positioning. Higher vocational colleges are mainly designed to serve for local economic development. Higher vocational colleges set up corresponding professions in accordance with the kinds of talents required by local construction and usually cultivate "short-term, even and fast-type" talents. A process is required to confirm and demonstrate he cooperative projects for Sino-foreign cooperative education. Besides, due to limitation of duration of time for application, conditions of application for cooperative projects are not complete demonstration is not sufficient, and a lot of projects are started in a rush. As a result, students recruited are not qualified or are unlikely to achieve the need of teaching, which is not able to guarantee quality of teaching. Even some projects are difficult to continue even though they have not reached the re-examination time limit of five years for cooperative education. Some projects come to a cease or are switched to some other professions when only one or two years of students are recruited. Some other projects have no other choice but to incorporate their students into other classes as they have not recruited a small number of students, or simply switch their students into other professions, as a result of which positioning of cooperative education seems chaotic. It is an issue that is urgently to be resolved how to combine Sino-foreign cooperative education and the actual situation of higher vocational colleges in China and form an accurate positioning of school running.

\section{The Problem of Administrative System of Foreign Teachers}

In Sino-foreign cooperative education in higher vocational colleges, since foreign teachers are mostly sent to 
China to teach by the cooperative institutions and are not invited by Chinese colleges, we can only offer explanation and persuasion to foreign teachers who have no high quality and ignore the administrative system of the colleges or propose a claim to the cooperative partners, but we have no right to dismiss these foreign teachers. Some foreign teachers are liberalized in the process of teaching and daily life as they have signed a short-term contract. It seems that the colleges have no other choice except that they have communication with the cooperative partners in the hope that their partners can strengthen administration on the foreign teachers sent, which brings certain difficulty to administrative job of the colleges.

Relevant department should set up a standard for school running in a scientific and reasonable way, make corresponding adjustment according to the actual situation and standardize management in terms of application approval, recruitment, charging and certificate on the basis of scientific, fair and justified principle. For consideration of sustainable development of Sino-foreign cooperative education, it is especially necessary to further improve the supervision system of Sino-foreign cooperative education and achieve scientificalness and standardization in terms of information management, annual examination management, supervision management and quality evaluation. It is also necessary to further strengthen guidance and leadership in Sino-foreign cooperative education in higher vocational colleges, positively carry forward high quality cooperative education and ensure scientific and sustainable development of Sino-foreign cooperative education.

\section{A Great Gap in Bringing in High-quality Education Resources}

First of all, the Sino-foreign cooperative education situation of "crying up wine and selling vinegar" has not been taken under supervision. According to "Questionnaire Survey Report on Internationalization of Education in Higher Vocational Colleges in Jiangsu Province", 45\% colleges operate school running at home in cooperation with foreign institutions and students involved each learn at home and abroad for a period of time. $60.5 \%$ of colleges mention that they operate school running at home in cooperation with foreign institutions and the entire teaching process is finished at home.

In the process of Sino-foreign cooperative education in higher vocational colleges, in order to enlarge the scope of school running as soon as possible and improve the level of school running, a large majority of the colleges take the initiative in exploring a new cooperative mode, create brand-new recruitment highlights and wish to bring in high quality educational resources under this kind of school running mode. However, some problems exist in this process, which makes the target unlikely to be well realized. For example, selection of cooperative partners is inappropriate. For pursuit of the signboard of "Sino-foreign cooperative education", some higher vocational colleges blindly select foreign institutions for cooperative education without making an adequate market survey and professional survey when the time is pressing. Furthermore, quality of foreign teachers is not high and the problem of irrational teacher structure is also quite prominent. In the process of specific implementation of the teaching plan, some foreign institutions are unlikely to send the excellent teachers in their institutions to the Chinese partners in order to reduce teaching costs or out of other considerations. Instead, they recruit some teachers temporarily in their countries, and some of them even recruit foreign teachers in China and then send these foreign teachers to the Chinese partner colleges. Most of these temporarily recruited teachers sign a short term contract with foreign cooperative institutions and some of them are even not excellent professional teachers in their field of study. Some are even totally not target grade and their basic quality can not be guaranteed, so they are dismissed and return to their countries once their contract is expired.

In addition, since teaching costs in Sino-foreign cooperative projects are relatively high, their charge of the tuition fee is generally three times or four times higher than a regular institution of higher learning. Some higher vocational colleges regard Sino-foreign cooperative education as a new highlight for growth of their recruitment and in order to cater to the "need" of the society and some parents, they blindly open a variety of newly emerging professions regardless of their own specific situation, such as, logistics, biological chemistry, E-business and so on. Some of them set up cooperative projects in total accordance with existing professions of the foreign partners. As a consequence, the students have no professional teachers to teach them after they enter the colleges and foreign teaching resources can not be guaranteed and it is too late to construct supporting laboratories and training bases, as a result of which students become the experimental game of the cooperative education.

In one word, ever since higher vocational colleges in Jiangsu Province started Sino-foreign cooperative education, they have achieved a series of important educational achievements, which has exerted great influences in all walks of life in the society. Nevertheless, we have to come to clear awareness that some problems are still concealed in cooperative education, such as, the problem of supervision in teaching by foreign partners, the problem of certification system about quality of cooperative education and the problem of copyright 
involved in using foreign teaching material, etc. All these difficulties constrain healthy development of Sino-foreign cooperative education in higher vocational colleges and it is a must to practically resolve these problems. Sino-foreign cooperative education in higher vocational colleges have to make clear the purpose of school running, rectify the idea of school running, grasp the rule of school running, enlarge vigor of publicity, set up and improve the supervision mechanism, ensure unchanged social public welfare of Sino-foreign cooperative education, guarantee that students' interests are not damaged and make both cooperative partners benefit therefrom. Only in that way, can the path of Sino-foreign cooperative education in higher vocational colleges become broader and broader.

With constant deepening of Sino-foreign cooperative education and introduction of advanced foreign vocational teaching ideas, it is imperative for higher vocational colleges to positively start bilingual teaching with the orientation of the employment market and the target of cultivating higher vocational college students with strong problem solving capacity and with an international field of vision. However, it is necessary to make adequate preparations in the aspects of teaching method and mode, teacher quality and construction of teaching material, regard the original knowledge system of Chinese students as the starting point, refer to successful cases both at home and abroad, try to explore a successful path for bilingual teaching in Sino-foreign cooperative education in higher vocational colleges and cultivate qualified international talents for socialist construction.

\section{References}

Wang, Y. H., Huang, Y., \& Li, M. (2008). Study on Some Issues in Sino-Foreign Cooperative Education. International Business-Journal of University of International Business and Economics (Supplement).

Zhang, Q. T. (2008). Status Quo, Problems and Countermeasures in Sino-Foreign Cooperative Education in Higher Vocational Colleges. Market Watch, (5). 